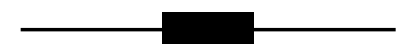

\title{
International Seminar on Museums and the Changing Cultural Landscape, Ladakh Conference and Project Report
}

\author{
Manvi Seth
}

The international seminar on Museums and the Changing Cultural Landscape, coordinated by Dr. Manvi Seth, was organized by the department of museology in the National Museum Institute of History of Art, Conservation and Museology in collaboration with the Ladakh Autonomous Hill Development Council (LAHDC) from 2-4 September 2012 at the Central Institute of Buddhist Studies (CIBS), Leh, Ladakh, India.

The aim of the seminar was to explore museums' potential to be platforms for documenting, representing, and communicating sociocultural change in the context of Ladakh. The seminar endeavored to encourage fellow museologists, museum professionals, and other scholars of culture and heritage studies to discuss, share, and advise on the possible forms of a museum for Ladakh. The intent was that the seminar would help initiate the process of planning a museum for Ladakh in a manner appropriate to the people and region.

Ladakh is one of the highest inhabited places on earth, with a culture that remained isolated for centuries. The heritage, natural and cultural, of the region is unique, the community is close knit, and the rich culture is ruffled by the ever-growing avalanche of tourists and the information explosion only in tourist spots and in the main city, Leh. There is a growing realization of the need to preserve cultural traditions alongside balancing the pressures of modern needs. In recent years there has been an increasing insistence in Ladakh that there should be a museum in Leh showcasing all aspects of Ladakhi culture. There are many monasteries in Ladakh that serve as museums of Buddhist religion, art, and culture; some of these monasteries have opened small museums and many others are in the process of setting up similar museums. The projected museum in Leh aspires to collect, document, and represent all aspects of a Ladakhi heritage, life, and culture in their tangible and intangible manifestations. It seeks to become a platform not merely for preserving physical collections but for connecting the younger generation with their own identity, for stimulating dialogue on the present issues concerning culture, and for providing a mechanism for understanding and channeling the future course of cultural change. It also hopes to answer questions such as: In view of fast-disappearing traditional community centers and cultural platforms, can museums fill the void of documenting and representing the past, present, and future of Ladakhi sociocultural stories and identities? How effective is the process of involving people at all levels in setting up a museum? Should not members of the community answer whether they require a museum in the first place and, if yes, what should be the form, nature, characteristics, and functions of such a museum? 
The seminar was attended by international scholars, museum experts, and academicians from other parts of India and by local Ladakhi scholars. It was very encouraging for the organizers and participants to have received messages from the president of the International Council of Museums (ICOM) and from UNESCO. Julien Anfruns, director general of ICOM, told the seminar, "I salute this initiative by our Indian colleagues to reflect upon the role that museums can fulfil within communities." Francesco Bandarin, assistant director general for culture at UNESCO, provided the following message, to be read at the inauguration: "From the outset, allow me to congratulate the department of Museology of the National Museum Institute (NMI) and the Ladakh Autonomous Hill Development Council for placing emphasis on community participation and the potential of museums to serve as platforms for socio-cultural change."

Paper presentations in the seminar were on various aspects of development of a museum, such as conceptualization, building of collections, documentation, communication, community participation, and intangible cultural heritage. Ladakhi scholars spoke about the cultural history of Ladakh; the cultural similarities between Central Asia and Ladakh; the memories and knowledge outside the monasteries; the Islamic and Buddhist heritage of Ladakh; the traditions of Ladakhi people; the need to preserve the intangible heritage of Ladakh; and much more. International speakers and scholars from other parts of India deliberated on theoretical and methodological issues, such as: why visit museums?; will the museum be an active or a passive space?; who are the audiences going to be?; documentation of cultural heritage; Ladakh as a cultural and living museum; the process of conservation and reconstruction; the importance of keeping alive the link between the object and its context; the need for keeping the visitors at the heart of the museum; making the community the stakeholder; cultural mapping; and so on. ${ }^{1}$

The seminar was accompanied by the opening, on 1 September 2012, of a photographic exhibition, The First Frames: In the Footsteps of Early Explorers. The exhibition brought to the people of Ladakh some of the earliest photographs of Ladakh and Tibet. The exhibition represented the collection of photographs and fresco tracings (1947-1949) of Li Gotami from the Chhatrapati Shivaji Maharaj Vastu Sanghralaya (CSMVS), Mumbai; the photographs of the German archaeologist August Hermann Francke (1909) from the digital photographic collection of the Library of the University of Leiden; and archival photographs (1960s) of Ladakh from the photo archives of Archaeological Survey of India (ASI). The exhibition aspired to rekindle, in these fast-changing times, memories of earlier life, culture, architecture, and religion in the Western Himalayan region.

Manvi Seth, National Museum Institute, New Delhi

\section{NOTE}

1. Presenters included: Monisha Ahmed, T. Richard Blurton, Nawang Tsering Shakjspo, G. M. Shiekh, Sonam Gyatso Tukchu, Yutaka Hirako, Lobzang Tsewang, John Harrison, Janhwij Sharma, Nelly Rieuf, Nawang Tsering Phey, K. Mukhoupadhyay, Soumendra Mohan Patnaik, Khanchen Tsewnag Rigzin, Eithne Nightingale, Xerxes Mazda, Karen Chin Ai Ying, Abdul Ghani Shiekh, Andrew Pekarik, Jamyang Gyaltson, Rajesh Purohit, Shaguna Gahilote, Gerda de Theuns Boer, Khanpo Konchok Phandey, Khonchok Rigzen, Anamika Pathak, R. C. Agarwal, Mika Nyman, Joyoti Roy, Ven Thupstan Paldan, Rama Lakshmi, Tsering Norbo Martse, Vandana Prapanna, Poulomi Das, Tsering Sonam, Nita Sen Gupta, and Chemmet Namgail. 